\title{
STUDENTS' INVOLVEMENT IN FORMATIVE ASSESSMENT AT UNIVERSITY LEVEL
}

\author{
Carmen Maria ȚîRU, Ph.D., \\ West University of Timişoara (Romania), Teacher Training Department, \\ E-mail: carmen.tiru@e-uvt.ro
}

\begin{abstract}
At any level of the educational process the common efforts of the teacher and students are reflected on the obtained and evaluated students' results. What is the students' involvement and decision in setting up the assessment criteria and instruments to asses these results at university level? How will students' results be affected by the possibility to choose some of these instruments and the number of participations in the formative examination? How will the formative assessment and the portfolio sustain personal and group progress? These are important questions for which this research will identify some possible analyses and conclusions. The research sample consisted in 71 second year students who were investigated during the first semester of 2018-2019 university year. Following the proposed assessment modalities and criteria, other teachers at university level could optimise the teaching process and the learning performance of their students.
\end{abstract}

Keywords: formative assessmentinstruments; personal involvement; formative assessment activity; portfolio.

\section{Introduction}

The issues of formative assessment at university level were characterised through diverse and complex approaches in the scientific literature. Most of the authors have studied formative assessment and its implications at university level from the following points of view: the implications of the feedback on the students' learning process (Sadler, 1998; Yorke, 2003; Higgins et al., 2001; Poulos \& Mahony, 2008; Carless, Joughin, Liu, \& Associates, 2006); teacher's specific modalities to give feedback to their students (Ott, Robins \& Shephard, 2016; Hattie, 2016; Brookhart, 2017 ) or to provide feedback for the adjustment of ongoing teaching and improving student achievement related to instructional objectives (Biggs, 2003); the influence and the effects of the use of different methods and instruments in the assessment process (Tang, 1994; Boud, 2006, 2007; Joughin, 2007). As we see, this issue is very complex and offers different perspective on how teachers at university level could use formative assessment in their day to day activity.

According to these approaches, the article tries to analyse formative assessment at university level from specific points of view: the student involvement in the assessment process and the influence of formative assessment and the portfolio on the obtained learning results. We considered the three approaches as fundaments for a possible proposal to develop a formative assessment process at university level.

\subsection{The students' involvement in the assessment process}

W. Astin (1984) defined the academic involvement as a complex of self-reported traits and behaviours (e.g., the extent to which students work hard at their studies, the number of hours they spend studying, the degree of interest in their courses, good study habits). In the formative assessment process students' involvement related to this approach could refer to: their participation in the development of the assessment criteria, choosing the assessment instruments and the marking system or the frequency of the assessment process. All these actions will contribute to a better acceptance of the assessment process and to a better mark 
obtained on the curricular content assessment. Regarding this fact, A. Lyons (1989, p. 37) argues that students' participation in the development of the criteria for assessment should manifest on a greater acceptance of the assessments made by the tutors.

Although the process of developing the assessment criteria is itself a learning experience because it determines the students to question what constitutes 'good' or 'bad' performance. Despite of these benefits, P. Orsmond et al. (2000) argued that students' involvement in the assessment process did not determine the possibility to discriminate between criteria given to them and those constructed by them and that the construction of the criteria does not increase the agreement between student and teacher or tutor. This is an issue that involves many individualised factors as personal beliefs and values, self-assessment criteria, the personal reflection process or the scientific level of knowledges on the evaluated discipline knowledges.

Involving students in the assessment process will assure the fundament for selfassessment and peer-assessment. For example, D. Dancer (2005) pointed that the subjectivity of the assessment process is minimized by involving students in the specification of clear criteria and the assessment process as they were asked to. For students this process is a long term one and supposes continuous and systematic steps and support from the part of the teacher. Also, teachers must be open to this form of cooperation and trust students for their capacity to understand and construct assessment criteria. Involved in the assessment process, students optimise their learning process and receive a better understanding of the curricular contents of the discipline.

\subsection{The formative assessment activities}

How often we do we use formative assessment at university level? Certainly, each course or seminary activity supposes a minimum feedback offered by the teacher to the students, students to students or students to teacher. But, within this relatively flexible approach, it is important to set up planned formative assessment activities (assessment on a specific subject matters). Some researchers pointed to the fact that students manifested positive responses when they have been surveyed about the value they place on organised formative assessment activities (Carroll, 1995; Rolfe and McPherson, 1995). This shows that the teacher has an important role in organising in a systematically and coherent manner the assessment activity with the participation of the students. Throughout this process the teachers' responsibilities are to assure the correspondence between the assessment tasks for the course/seminary competences and objectives, to choose and to build up the assessment methods and instruments, to set up a calendar for the formative assessment activities and the related activities and to give personal formative feedback to students on the obtained performance. Also, the students must be involved in each previously mentioned action, having the opportunity to choose the number of participations, the assessment instruments and the expected level of performance.

It is a fact that much of the planned formative assessment has been conducted with teacher-oriented requirements which included testing the class's general level of understanding on the curriculum and not giving attention to students' consequential action (Yorke, 2003). For attending this requirement, it is important that the teacher chooses specific assessment instruments. These instruments will give the students the possibility to learn continuously and systematically and to observe their evolution related to the expected competences. Only teachers who give feedback on these issues for each student and each assessment activity could assure and support students' performances and implication. 


\subsection{The portfolio and the assessment process}

L.A. Shepard (2000) argued that, whilst approaches to learning have moved in the direction of constructivism, approaches to assessment have remained inappropriately focused on testing. The test is one of the most used assessment methods, which is also the most objective assessment instrument. But, from the student's involvement perspective in the assessment process the test is not very efficient: the teacher creates some items which are focused on the curricular content and only a very few types of items could evaluate skills or attitudes. We have previously mentioned the importance of students' implication in choosing the assessment instruments and the students' involvement in the formative assessment process. In this respect, one of the modern assessment methods is considered the portfolio, which assures a good understanding of the criteria involved and the agreement between assessors (Ben-David, 2000). The students could personalise their portfolio respecting also the assessment criteria proposed by the teacher.

Different researches offered various perspective on this method of assessment. For example the following issues were approached by the educational researchers: the importance of establishing the purpose of the portfolio, the impact of portfolio on learning, teaching and professional development processes (Klenowski, Askew \& Carnell, 2006); the facilitation of student centred learning through assessment using portfolios (Brown, 2002); the role of the portfolio in student self-assessment and the reflection on the learning process and products (Andrade \& Cizek, 2010; Alonso-Tapia, 2002; Brookhart, 2008; Danielson, \& Abrutyn, 1997; Wolf, 1989); the usage of the e-portfolio in the educational process (Pitts \& Ruggirello, 2012).

The portfolio exceeds the limits of tests and accompanies the students' route from the beginning to the end of the educational activities. This method offers support to students for improving their learning process and for teachers also for optimising or changing their teaching process. Also, permanent and formative feedback between teacher and students is assured, but also between students and their colleagues.

\section{The research methodology}

Our research was focused on the following aim: to offer a proposal for developing students' involvement in the formative assessment process at university level and of ascertaining the effect of this involvement on the learning results. Our hypothesis was that using different modalities to involve students in the formative assessment process will improve their learning performances.

The objectives of the research were to:

Q1. Set up the modalities to involve the students in the formative assessment process at university level;

Q2 Establish the impact of using the formative assessment and the portfolio on the students' obtained results;

Q2. Setting up a formative assessment proposal which could be used in the academic formative assessment process.

The target group of the research were 71 second year students which were investigated during the first semester of 2018-2019 university year at Teacher Training Department (course and seminary activities for the Pedagogy II discipline). We analysed the impact of using our formative assessment proposal on the students' results in a qualitative and quantitative manner.

The analyses of the results (qualitative and quantitative) are presented below and refer to the three characteristics of the implemented formative assessment:

The students' involvement in the assessment processwas manifested in the following ways: 
-During the seminar activity -

At the beginning of the semester the students chose the percentage for each piece of the portfolio $(60 \%$ the lesson project; $20 \%$ the application of a teaching method on subject from the content of their specialization- and $10 \%$ the workpapers done during the classroom activities and $10 \%$ the intervention in the seminary activities). Also, the students expressed their opinion on the portfolio pieces, on the deadline and possibility to optimise their obtained mark. The students chose the subject for the designed lesson from the gymnasium syllabuses for each specialisation, the type of the lesson and a minimum three workpapers done during the classroom activities.

-During the course activity -

The students had the option to keep or renounce the obtained mark from each formative assessment activity. In the case that they kept their mark for each formative assessment activity (to time evaluation on different contents), the assessment items were only for the specific assessment content (the third formative assessment activity' content). In the case that the students renounced any formative assessment activity mark, they would be assessed on these contents in the final examination.

The formative assessment activities were three, two of them during the semester (on established date and only one was compulsory) and one in the final examination (the compulsory semester examination). Only 4 students did not participate in all the three assessment, choosing only 2 participations (the first and the third formative assessment).

The curricular contents and the dates of examinations were established by the teacher and communicated at the beginning of the semester. Also, the teacher explained the modality to calculate the final mark for the course and the final mark for the discipline. Each course support was accompanied by possible issues/items for the formative assessment activity. The teacher prepared various and different types of assessment items: for the 1 and 2 assessment activities: multiple choice, completion items, correlation items; and open responses at the 3 formative assessment activity. For the final examination activity, the assessment items were centred on the skills to develop a topic in a scientific and personal manner.

The portfolio was constructed on the following pieces: the lesson project; the application of a teaching method in their specialization and minimum three workpapers done during the classroom activities. The deadline for the project lesson was commonly established with the students and each of them had the possibility to redo their project one time following the teacher indications and suggestions, if they wanted to. The second piece of the portfolio was presented in an applicative manner, each of them choosing the modality to interact with their colleagues and identify in which way they could use it in teaching a subject from their specialisation. The workpapers done during the classroom activities were individual or group activity sheets which reflected students' work and the involvement in the classroom activities. For each workpaper, every student received an immediate feedback from the teacher and from colleagues. $92,5 \%$ of students optimised their project lesson after the teacher's feedback and obtained a better mark on it.

The table presented below (Table 1.) shows the students means for each assessment activity (1, 2 and 3-the final examination) and for the final mark obtained by students $(66 \%$ the mean between the three examination 'mark and 33\% the mark obtained for seminary: portfolio and personal involvement at the seminary activities). 
Table 1. Formative assessment activities' results comparison

\begin{tabular}{|c|c|c|c|c|c|}
\hline $\begin{array}{l}\text { Pair } \\
\text { sample }\end{array}$ & $\begin{array}{l}\text { Formative assessment } \\
\text { activities pairs }\end{array}$ & Mean & $T$ & Df & Sig. (2-tailed) \\
\hline Pair 1 & $\begin{array}{l}\text { assessment activity1 - } \\
\text { assessment activity2 }\end{array}$ & $7,27-7,46$ &,- 871 & 61 & $\begin{array}{r}, 387 \\
\mathrm{p}>0.05 \\
\end{array}$ \\
\hline Pair 2 & $\begin{array}{l}\text { assessment activity1 - } \\
\text { assessment activity3 }\end{array}$ & $7,27-8,08$ & $-5,205$ & 61 & $\begin{array}{r}, 000 \\
\mathrm{p}<0.01 \\
\end{array}$ \\
\hline Pair 3 & $\begin{array}{l}\text { assessment activity1 - } \\
\text { assessment activity4 }\end{array}$ & $7,27-8,53$ & $-10,292$ & 61 & $\begin{array}{r}, 000 \\
\mathrm{p}<0.00 \\
\end{array}$ \\
\hline Pair 4 & $\begin{array}{l}\text { assessment activity2 - } \\
\text { assessment activity3 }\end{array}$ & $7,46-8,08$ & $-7,504$ & 61 & $\begin{array}{r}, 000 \\
\mathrm{p}<0.01\end{array}$ \\
\hline Pair 5 & $\begin{array}{l}\text { assessment activity2 - } \\
\text { assessment activity4 }\end{array}$ & $7,46-8,53$ & $-3,324$ & 61 & $\begin{array}{r}, 002 \\
\mathrm{p}<0.01\end{array}$ \\
\hline Pair 6 & $\begin{array}{l}\text { assessment activity3 - } \\
\text { assessment activity4 }\end{array}$ & $8,08-8,53$ & $-4,409$ & 61 & $\begin{array}{r}, 000 \\
\mathrm{p}<0.01\end{array}$ \\
\hline
\end{tabular}

Analysing the previous table, we observe that was a significant difference between the means in each correlation possibility $(p<0.01)$, except for the correlation between the means obtained at the formative assessment activity 1 and formative assessment activity 2 $(\mathrm{t}=0.871$ and $\mathrm{p}>0.05)$. Probably because the two formative assessment activity ( 1 and 2$)$ were relatively close to each other in time and the students did not have enough time to optimise their learning style. Also, each of the means are up to 7 points (out of 10), which is a good score.

We think that the significative grow of the means from assessment activity 2 to assessment activity 3 was based on the specific feedback given by teacher for each student assessment paper, but also due to the longer time for preparing and optimising the assessment items/requirements. It is a significant difference between the means obtained at the assessment activity 1 and assessment activity $3(\mathrm{t}=-5,205$ and $\mathrm{p}<0.01)$ and between assessment activity 2 and assessment activity $3(\mathrm{t}=-7,504$ and $\mathrm{p}<0.01)$. So, the students had time to get used to the specificity of curricular contents and a better understanding of the discipline itself. The type of items (open responses with personal approach) were preferred (assessment activity 3) than the items used in assessment activity 1 and 2 formative assessment activities.

The fact that there was a significant difference between the means obtained at the assessment activity 1 and assessment activity 4 (final mark: 66\% the course mark and 33\% the seminary mark) is shown by $\mathrm{t}=-10,292$ and $\mathrm{p}<0.01$ which demonstrates that the formative assessment proposal optimised students' learning process and their involvement in the assessment process stages.

\section{Conclusions}

Formative assessment is an important issue in higher education and the focus on more frequent and better developed formative assessment needs to be addressed within curricular developments (Knight 2000). Analysing the obtained results, we can conclude that the formative assessment process at university level is fundamental for developing students' involvement in the teaching, learning and assessment processes. The manner or the methods and instruments which will be used in the formative assessment process depends on the teacher and students, process in which they will be coparticipants.

As we have previously seen, the teacher has the principal role in setting up the entire structure of the formative assessment plan. He constructs the assessment instruments and prepares models for assessment on each course subject matter. Also, the teacher develops different types of items/ requirements for each course unit, covering the whole curricular 
content and skills that will be assessed. Each formative assessment activity must be well prepared, and the calendar commonly established with the students. It is important that the assessment activities should be distributed according to the difficulty level and volume of the evaluated curricular content. The students' involvement in each stage is very important.

From the beginning, this type of assessment process must be a collaborative one, giving the students the possibility to choose the type of assessment and the frequency of their participation in the assessment activities. Knowing the type of the assessment instruments/items/requirements for the beginning, the students' involvement in the learning process will develop and will be reflected (as we previously have seen) on the growth of their marks' mean (which proves the optimisation of their results).

Continued and objective feedback is necessary for an efficient formative assessment. Throughout our research feedback has accompanied each assessment activity (per individual as obtained mark and per group as obtained mean of marks) and each piece of portfolio (for each student). In this respect, the feedback was given by the teacher also on each piece of the portfolio used for our research and it was important for students' learning improvement. As we demonstrated, a high percent of students revised their lesson plan and obtained a better mark. We also asked for students' feedback on their colleagues' activity. The feedback functioned as a support for better learning of the students and for a higher score.

At the end of the semester, the teacher presented the students' progress statistically and used a motivational text, as the following:

Dear students,

Here's how you've completed another discipline ...It was a common effort and I thank you for the progress that you have made, both individually and at the group level! Bellow I am presenting the results of your work (the average of all participants on each assessment activity). Notice that there has been a significant growth regarding the mean of your marks during the semester and that the final average is high. Even though the statistical average does not reflect the individual progress of each one, I have seen and tried to appreciate it correctly. I hope that the competencies you have gained will be useful for you, both in the following activities of this programme and for a future teaching career. I wish everyone to have success in all your future educational activities!

Although the growth should be natural from the beginning to the end of a discipline engagement, this does not happen when the assessment process is summative. The shadow of summative assessment has never been far away, and each academic teacher is very likely to have to switch roles from that of supporter of learning to the assessor of achievement (Yorke, 2003). For avoiding this issue, each university teacher must use formative assessment constantly and involve students in every stage of this process.

\section{References}

Alonso-Tapia, J. (2002). Knowledge assessment and conceptual understanding. In M. Limón \& L. Mason (Eds): Reframing the processes of conceptual change. (pp. 389-413). Dordretch, the Netherlands: Kluwer.

Andrade, H., \& Cizek, G. J. (2010). Students as the definitive source of formative assessment: Academic self-assessment and the self-regulation of learning. In Handbook of formative assessment (pp. 102-117). Routledge.

Astin, A. W. (1984). Student involvement: A developmental theory for higher education. Journal of college student personnel, 25(4), 297-308.

Ben-David, M. F. (2000). The role of assessment in expanding professional horizons. Medical Teacher, 22(5), 472-477.

Biggs, J. (2003). Aligning teaching and assessing to course objectives. Teaching and learning in higher education: New trends and innovations, 2(April), 13-17. 
Boud, D. (2006). Foreword. In C. Bryan \& K. Clegg (Eds.), Innovative assessment in higher education (pp. xvii-xix). London and New York: Routledge.

Boud, D. (2007). Reframing assessment as if learning were important. In D. Boud \& N. Falchikov (Eds.), Rethinking assessment in higher education: Learning for the longer term (pp. 14-25). London and New York: Routledge.

Brookhart, S. (2008). Portfolio assessment. In T. Good (Ed.), 21st century education: A reference handbook, volume 1 (pp. 443-450). Sage.

Brookhart, S. M. (2017). Formative assessment in teacher education. International handbook of research on teacher education, 927-943.

Brown, C. A. (2002). Portfolio Assessment: How Far Have We Come? https://files.eric.ed.gov/fulltext/ED477941.pdf.

Carless, D., Joughin, G., \& Liu, N. F. (2006). How assessment supports learning: Learningoriented assessment in action (Vol. 1). Hong Kong: Hong Kong University Press.

Carless, D., Joughin, G., Liu, N-F., \& Associates (2006). How assessment supports learning: Learning-oriented assessment in action. Hong Kong: Hong Kong University Press.

Carroll, K. M. (1995). Methodological issues and problems in the assessment of substance use. Psychological Assessment, 7(3), 349.

Dancer, D., \& Kamvounias, P. (2005). Student involvement in assessment: A project designed to assess class participation fairly and reliably. Assessment \& Evaluation in Higher Education, 30(4), 445-454.

Danielson, C., \& Abrutyn, L. (1997). An Introduction to Using Portfolios in the Classroom. Association for Supervision and Curriculum Development, 1250 N. Pitt Street, Alexandria, VA 22314-1453.

Hattie, J. (2016). Know thy impact. On Formative assessment: Readings from educational leadership (EL Essentials), 36.

Higgins, R., Hartley, P., \& Skelton, A. (2001). Getting the message across: the problem of communicating assessment feedback. Teaching in higher education, 6(2), 269-274.

Joughin, G. (2007). Student conceptions of oral presentations. Studies in Higher Education, 32(3), 323-336.

Klenowski, V., Askew, S., \& Carnell, E. (2006). Portfolios for learning, assessment and professional development in higher education. Assessment \& Evaluation in Higher Education, 31(3), 267-286.

Knight, P. (2000). 'The value of a programme-wide approach to assessment', Assessment and Evaluation in Higher Education 25(3), 237-251.

Lyons, P. R. (1989) Assessing classroom participation, College Teaching, 37(1), 36-38.

Orsmond, P., Merry, S. \& Reiling, K. (2000) The use of student derived marking criteria in peer and self-assessment, Assessment and Evaluation in Higher Education, 25(1), 23-38.

Ott, C., Robins, A., \& Shephard, K. (2016). Translating principles of effective feedback for students into the CS1 context. ACM Transactions on Computing Education (TOCE), 16(1), 1 .

Pitts, W., \& Ruggirello, R. (2012). Using the e-Portfolio to Document and Evaluate Growth in Reflective Practice: The Development and Application of a Conceptual Framework. International Journal of ePortfolio, 2(1), 49-74.

Pitts, W., \& Ruggirello, R. (2012). Using the e-Portfolio to Document and Evaluate Growth in Reflective Practice: The Development and Application of a Conceptual Framework. International Journal of ePortfolio, 2(1), 49-74.

Poulos, A., \& Mahony, M. J. (2008). Effectiveness of feedback: The students' perspective. Assessment \& Evaluation in Higher Education, 33(2), 143-154.

Rolfe, I., \& McPherson, J. (1995). Formative assessment: how am I doing? The Lancet, 345(8953), 837-839. 
Sadler, D. R. (1998). Formative assessment: Revisiting the territory. Assessment in education: principles, policy \& practice, 5(1), 77-84.

Shepard, L.A. (2000). 'The role of assessment in a learning culture', Educational Researcher 29(7), 4-14.

Tang, K. C. C. (1994). Effects of modes of assessment on students' preparation strategies. In G. Gibbs (Ed.), Improving student learning: Theory and practice (pp. 151-170). Oxford, England: Oxford Centre for Staff Development.

Wolf, D. (1989). Portfolio assessment: Sampling student work. Educational Leadership, 46(7), 35-39.

Wolf, D. P. (1989). Portfolio assessment: Sampling student work. REPORT NO PUB DATE, 351.

Yorke, M. (2003). Formative assessment in higher education: Moves towards theory and the enhancement of pedagogic practice. Higher education, 45(4), 477-501. 